Kliestik, T., Valaskova, K., Lazaroiu, G., Kovacova, M., \& Vrbka, J. (2020). Remaining Financially Healthy and Competitive: The Role of Financial Predictors. Journal of Competitiveness, 12(1), 74-92. https://doi.org/10.7441/joc.2020.01.05

\title{
REMAINING FINANCIALLY HEALTHY AND COMPETITIVE: THE ROLE OF FINANCIAL PREDICTORS
}

\section{- Tomas Kliestik, Katarina Valaskova, George Lazaroiu, Maria Kovacova, Jaromir Vrbka}

\begin{abstract}
Financial ratios play an important role in revealing corporate financial soundness, a role which helps to maintain the competitive position of an enterprise, with the achievement of stable development contributing to the elimination of potential financial risks. This paper aims to analyse and compare financial ratios used in the models of transition countries. The analysis focuses on the prediction of the future financial development of a particular enterprise as well as the determination of potential dependencies among the nation in consideration of financial ratios and country of origin. More than 400 prediction models of the Slovak Republic, the Czech Republic, Poland, Hungary, Romania, Lithuania, Latvia, Estonia, Croatia, Russia, Ukraine and Belarus were analysed. The crucial significance of financial ratios in divergent conditions is revealed using a cluster analysis, categorical data and a correspondence analysis. The cluster analysis identified similarities among three groups of countries: i) Belarus, Estonia, Croatia and Latvia; ii) Lithuania, Russia, Hungary and Ukraine, and iii) Czech Republic, Slovakia, Romania and Poland. The results of the correspondence analysis indicate that the individual groups of countries prefer different financial ratios in developing models of prediction of financial distress, differences which arose as a consequence of common changing political, market and economic conditions within each group of nations. In contrary to results suggested by our findings, the most frequently used financial ratios in the prediction models throughout the countries remain current ratio, total-liabilities-to-total-assets ratio, and total-sales-to-total-assets ratio.
\end{abstract}

Keywords: competitiveness, bankruptcy prediction, financial distress, financial ratio, Eastern European countries

JEL Classification: O11, M23, L13

Received: December, 2019

1st Revision: February, 2020

Accepted: February, 2020

\section{INTRODUCTION}

Financial health is one of the best indicators of an enterprise potential for long-term growth and for a successful operation in the competitive market environment. The enterprises with 
the financial health-oriented strategy can enjoy a competitive advantage. Financial ratios have traditionally been indicators of a corporate overall performance (Rahman et al., 2017) and may help quantify a potential impact of internal ratings on financial performance (Belas et al., 2012). Measuring and assessing the financial ratios of profitability, activity, liquidity and indebtedness help create a competitive advantage for an enterprise. However, symptoms of financial distress never occur at the same time but in certain phases. First, there is a decrease in output volume, a decrease in profitability, an increased need for working capital, a deterioration of the capital structure and finally, it comes to persistent insolvency. Financial difficulties can be easily deduced from the financial statements, as the unanticipated or unusual development or change in the ratios may reflect some problematic areas. Moreover, the identification of crucial predictors can help enterprises assessing their future development (Valaskova et al., 2018). Accounting based on financial distress indicators is still actively used among researchers and widely used as a selection criterion (Gavurova et al., 2017; Belas et al., 2018a). The identification of significant financial indicators presents the opportunity of modelling the probability of failure and prediction of financial difficulties even despite the critique the financial indicators are calculated ex post. However, experience and abundant development of methods predicting the financial situation of an enterprise in the future indicate that the corporate financial ratios bring the information, which is necessary. As stated by Virag (2004), ratios may apply to any quantity shown in the financial statement, although, the choice is restricted only by the fantasy of the analyst or by the number of items in the financial statement.

The originality of the research lies in exploring the role of financial ratios in the prediction of financial distress in economic conditions of transition economies, where the financial ratios of more than 400 models were analysed and assessed, which makes the study pioneering considering the number of the reviewed models. Thus, the intention of the article is to clarify the role of the financial ratios in the prediction of financial distress in an analysis considering the multiple country samples of business entities of transition economies. The research problem includes the application of several statistical methods used to reveal the dependence among the financial ratios, method of bankruptcy prediction and country of the model origin, based on the cluster analysis, categorical data and correspondence analysis. Considering various models of the bankruptcy prediction of transition economies (Kliestik et al., 2019) help judge if the countries with similar economic development and market transformation use the same indicators when assessing the financial health of business entities. We confirmed that specific groups of countries apply and prefer different financial ratios when developing the model of the prediction of financial distress.

The paper is divided into four main parts. The literature review portrays the latest research and studies being conducted in the field of the bankruptcy prediction. Data and Methods depicts a brief description of 175 models of Eastern European countries, considering the number of models being developed in individual countries, methods used and numbers of financial ratios used in the models. This section portrays the individual steps of empirical analysis. The Results section describes all the important findings, resulting in the correspondence map, which is used to match the countries and most frequently financial ratios following specific economic and political conditions of the nations. The Discussion part highlights the crucial results and compares the 
identification of the most significant financial ratios with other studies devoted to the detection of important financial ratios in the process of the bankruptcy prediction.

\section{THEORETICAL BACKGROUND}

There are currently a few hundreds, perhaps up to thousands of prediction models that have been developed at a specific time and under the conditions of specific economies. By now, many models of the bankruptcy prediction have been introduced, but this research area remains a field of a constant research activity (Zelenkov et al., 2017). The basic question that the authors of the models had to ask is when we can consider the business financially sound and when it is on the way to any form of financial distress, failure or bankruptcy. Fitzpatrick (1932) was one of the first to define financial distress. According to his study, financial distress is the corporate inability to repay its financial obligations after their maturity. Beaver (1966) pointed out that financial distress can manifest itself in various forms depending on the type of event that occurred - bankruptcy, uncovered bond, bank overdraft or non-payment of a priority share dividend.

The company is in a state of distress when it misses interest payments or does not keep loan agreements. As claimed by Kljucnikov et al. (2017) and confirmed by Hudakova et al. (2018), the payment discipline issue and its consequences, including the risk of insolvency and lowered competitiveness, play an important role in the prediction of distress and in the business efficiency maximization (Dobrovic et al., 2018). Svabova et al. (2018) say that the transformation from a state of solvency to insolvency occurs only on the due date if the present value of an enterprise's assets is lower than the nominal value of the debt. The financial distress very often leads to a bankruptcy. An enterprise with financial problems has the opportunity to reorganize corporate debts and to achieve a reasonable level of solvency, or to merge, thereby ceasing to exist as a newly established enterprise or to file for bankruptcy as a managerial and shareholders answer to corporate financial problems (Ishtiaq et al., 2018). The notion that financial distress is a separate economic category was used in the model by Turetsky \& McEwen (2001). Corporate financial problems may be defined as a series of mutually connected levels specified by a particular set of unfavorable financial operations (Belas et al., 2018b). Each level of financial problems has an emergency moment and continues until another emergency moment is achieved. In general, financial problems may be determined as the distance between two emergency moments. Financial distress starts with an essential decline from positive to negative cash flow. The following decrease in dividends signals a change to the next stage leading to insolvency. The deterioration of the financial health of the company on three levels or dimensions defined by Darmawan \& Supriyanto (2018) are economic distress, financial distress and liquidity distress. Fogarassy et al. (1999) identify financial distress as negative operating income or net pre-tax profit for min. three successive years. From the outputs of the research analysis of dividend policy in the time of corporate financial problems, they conclude that when financial distress starts to occur, the company is typically experiencing difficulties with cash flow and not being able to pay out dividends. For this reason, a quick and aggressive reduction of dividends along with the following negative earnings can be used to determine the level of financial distress. Goldston (1992) presents a partly quantitative view of financial distress and lists the symptoms of financial distress as a decline in operating profit of 5\% per annum, a year-on-year decline in market share, 
quality managers departure to competition, declining levels of business capabilities, decrease of the ability to generate cash, increase in inventory of finished products, reduction of $\mathrm{R} \& \mathrm{D}$ expenditure, cannibalization of the company's new products on the market, production capacity is at the level of $60 \%$ and the company has a contract volume of production lower than $10 \%$ of an annual planned production. Asquith et al. (1994) tried to explain the corporate financial distress using the interest coverage ratio. An enterprise is in financial problems if in any of the two successive years its EBITDA is less than $80 \%$ of the company's interest expense. Using these methods means that the analysts may estimate the financial distress by a decline in profitability or insufficient cash flow level, which cannot cover the corporate liabilities. Platt \& Platt (2002) emphasize the deficiency of a uniform definition of the situation when a financial distress occurs in an enterprise and attempts to epitomize various operational determinations of financial distress in one way. An enterprise is experiencing financial distress if any of the mentioned situations arises: it has been experiencing few years of negative net operating revenues or a stoppage of dividend payouts, financial restructuring or massive lay-offs take place.

Developing the prediction model in conditions of the Slovak Republic (Kliestik et al., 2018), the authors focused on indicators determined by prominent authors as key predictors of financial health and analyzed studies and researches of Sharifabadi et al. (2017); Tian et al. (2015), Bellovary et al. (2007), Ravi \& Ravi (2007) and Dimitras et al. (1996). Virag (2004) lists discriminating financial ratios the most frequently used in bankruptcy models: cash flow to total liabilities, cash flow to long term liabilities, EAT to total assets, total liabilities to total assets, net working capital to total assets, liquidity ratio, funds to short term liabilities and net working capital to sales. Andrés et al. (2012) consider a set of 22 financial ratios to assess the financial situation of a company. In their selection process, they considered previous research on the determinants of profitability and bankruptcy. Besides, other authors have included various indicators of liquidity, indebtedness, asset turnover, efficiency and productivity, margin, growth, financing cost and profitability indicators in their studies. Antonowicz (2014) analyzes the productivity of the corporate assets applying five chosen ratios, which are the most important financial indicators used in the financial-economic analysis of enterprises. Those are: (i) general assets productivity ratio, which is a ratio of revenues from sales to the average annual value of assets; (ii) profit/loss on sales to the average annual balance sheet total ratio; (iii) return on investment (ROI), which is a relation of the result on the operating activity to the average annual value of assets; (iv) gross asset productivity ratio, which is the gross financial results to the company's total assets involved in economic processes; (v) return on assets (ROA), which is a net financial result to the average annual value of the total value of assets. Bahiraie et al. (2011, p. 957) present a complex methodology to analyze corporate financial indicators and predict the bankruptcy problems using a list of 40 highly regarded financial ratios. These indices reflect different aspects of firm structure and performance: liquidity, turnover, operating structure and efficiency, capitalization and profitability. Beaver et al. (2005) and Beaver et al. (2012) explore the effect of differences in financial reporting and focus on attributes of the predictive ability of financial ratios of bankruptcy. In addition, important implications for bankruptcy prediction research and practice, especially in terms of identifying the most important financial predictors, were unveiled in the research of Lukason \& Laitinen (2019). 


\section{RESEARCH OBJECTIVE, METHODOLOGY AND DATA}

The recent research in this field indicates that the interest of researchers and academicians in the bankruptcy prediction modelling has not been abated. In recent years, weakened by the fall of economic growth, many enterprises fell into a crisis caused by financial difficulties (Le et al., 2018). Thus, the paper aims to analyze and compare the financial ratios used in the models of the transition countries focused on the prediction of future financial development of an enterprise and its competitive position, and to find any dependencies among them considering the financial ratios and the country of origin.

After an extensive study of journal articles, books and monographs published in the period 1993 to 2018 (after the vast majority of European countries finished their economic transformation), we identified more than 400 models being developed and applied in Eastern European countries to predict the financial performance of enterprises in the future; not all of them were used in the research due to missing, not available and ambiguous data. However, 180 models used to predict future financial situation of an enterprise, considering the models being formed in transition economies, mostly in the European ones - the Czech Republic, Slovakia, Poland, Hungary, Croatia, Latvia, Estonia, Lithuania, Romania, Belarus, Ukraine and Russia were analyzed. The study reveals that 63 studies were developed in Poland, which is the leader in the formation of prediction models, more than 20 models were formed in Romania and the Czech Republic, more than 10 in Slovakia, Ukraine and Russia. Thus, considering the country of origin, 57\% of all prediction models were formed in Eastern Europe, especially in the countries of the Visegrad group, which may be an indicator of difficult competitive market, legislative obstacles, national and political backgrounds of the countries. The fact is that the prediction of business failure is realized using different statistical methods. Except for the standard statistical methods used for the bankruptcy predictions (discriminant analysis, logistic regression or principal component analysis), some researchers attempt to use newer significant methods, e.g. Technique for Order Performance by the Similarity to Ideal Solution (Ouenniche et al., 2018) or convolutional neural networks (Hosaka, 2019; Vochozka, 2017). Garcia et al. (2019) affirm that the corporate bankruptcy prediction has widely been studied as a binary classification problem using both advanced statistical and machine learning models. The research on prediction models in transition economies reveals that authors prefer to use the discriminant analysis (101 studies), mainly the linear, multiple and quadratic discriminant analyses, and then conditional probability (logit and probit models) used in 48 studies, neural networks (artificial neural networks, adaptive networkbased fuzzy inference system, self-organizing map and fuzzy logic), decision trees (regression trees, RE-EM, CHAID), data envelopment analysis, principal component and cluster analyses, and some others. However, both the national, political, legislative and economic conditions of a country where the prediction model was developed and the statistical method used are important measures. The study of different models further reveals that the various number of financial ratios is used as independent variables entering the model. The results prove that it is optimal to use three to six ratios entering the prediction model.

The mutual relations among the factors are investigated using several statistical methods. The use of the cluster analysis focuses on the identification of homogenous subgroups of the dataset to sort the objects into clusters so that the objects within a common cluster are from as much 
similar as possible, objects in different clusters are significantly divergent. Thus, the structure of the data is unveiled. To use the method, the calculations have to meet few preconditions: (i) there are no outliers and not available of missing data in the dataset; (ii) it is appropriate to have standardized variables and (iii) the results may be negatively influenced by the existence of dependence among the variables. The choice of the proper measurement method depends on the analyst and the character of the application solved. However, the most common measures are the Euclidean distance and Manhattan distance. To cluster the countries in which the models were developed and the financial ratios used to predict the financial distress, authors use the heuristicbased agglomerative hierarchical method of clustering, specifically Ward's method and squared Euclidean distance, calculated as (Eq. 1):

$d_{i j}=\sum_{k=1}^{K}\left(x_{i k}-x_{j k}\right)^{2}$,

where $x_{i k}$ is the value of the $k$-th variable of the $i$-th object and $x_{j k}$ is the value of the $\mathrm{k}$-th variable of the $j$-th object. The Euclidean distance was used following the basic assumption of the noncorrelated variables entering the cluster analysis. Each node represents a single cluster at the beginning; eventually, nodes start merging based on their similarities and all nodes belong to the same cluster (Hexmoor, 2016). The results of the cluster analysis are presented in a dendogram, which illustrates the arrangement of the clusters produced by the corresponding analyses.

The correspondence analysis is an analogy of the principal components analysis and factor analysis of qualitative data in contingency tables (Clausen, 1998; Stevens, 2002). To examine the internal structure of the contingency tables only makes sense if there is any statistically significant dependence between the monitored factors. The use of correspondence analysis is, therefore, restricted to the hypothesis testing of the independence of selected factors in the contingency table. The authors tested the hypothesis using the Pearson Chi-square test of independence. If the testing results as for the rejection of a hypothesis about the independence of the factors being monitored (we consider the significance level of $1 \%$ ), it makes sense to investigate which categories of factors are similar to each other. The similarity is observed within the category of one factor, i.e. in the row or columns of the contingency table, or, on the contrary, within the different categories of factors. Considering the practical application of the method, it is desirable to identify visually the relations between rows and columns of the contingency table. Therefore, it is necessary to find the projection of the points of the multidimensional space representing rows and columns of the contingency table into the plane, thus obtaining the correspondence map, where the Euclidean distance of the plane points approximates the original $\chi^{2}$-distance of the points of the multidimensional space. It should be the projection which preserves the relationship between the points of the multidimensional space as much as possible, therefore, the matrix of standardized residues $\mathrm{Z}$ is used, where the factor in the $\mathrm{i}$-th row and $\mathrm{j}$-th column is defined using the elements of the correspondence matrix and their marginal sums, defined by the equation (Eq. 2):

$z_{i j}=\frac{p_{i j}-p_{i . p_{. j}}}{\sqrt{p_{i} p_{j}}}$. 
When looking for a suitable projection, it is inevitable to apply the singular decomposition to the matrix and combine the result with matrices derived from row and column loads to get the axes of individual row and columns. This way of calculation allows influencing how the points of the multidimensional space are displayed in a plane (how the correspondence map is formed) - if the mutual comparison of rows or columns is important or their simultaneous comparison. The closer the points in the correspondence map, the more similar are the categories and the stronger their mutual correspondence. It is also important to determine the degree that characterizes the quality of the transformation of multidimensional points into a correspondence map. The transformation is considered appropriate if it retains the maximum proportion of the variability of multidimensional points. The variability measure is the total inertia, which is the weighted sum of the squared $\chi^{2}$-distance between each row profile and the average row profile, and is defined as follows (Eq. 3):

$I^{2}=\sum_{i} p_{1+} d_{i}^{2}$

where I if the total inertia, $p_{i}+$ is the marginal relative frequency of row $i$ and $d_{i}$ is the $\chi^{2}$-distance between row i's profile (Kral et al., 2009) and the average row profile calculated as (Eq. 4):

$d_{i}=\sqrt{\sum_{j} \frac{\left(p_{i j}-p_{+j}\right)^{2}}{p_{+j}}}$,

where $p_{i j}$ are relative frequencies for row $i$ and $p+j$ is the marginal relative frequency for column $j$. Column categories are determined analogically.

\section{RESULTS AND DISCUSSION}

In order to determine the role of financial ratios in the prediction of financial distress, considering the country where the prediction model was developed, method and number of variables entering the model, it was necessary to create a cluster of countries and financial ratios. Using the cluster analysis enables to find the dependence among the factors under investigation and help reveal the importance of financial ratios in predictive studies. The use of cluster analysis allows searching and identifying homogeneous subgroups of the specific selected factors. The resulting dendogram unveils the following 3 clusters:

- Cluster 1: Belarus, Estonia, Croatia and Latvia

- Cluster 2: Lithuania, Russia, Hungary and Ukraine

- Cluster 3: Czech Republic, Slovakia, Romania and Poland.

It is notable that the created groups of countries correspond with the classification of the European countries by Bukharin \& Preobrazhensky (2007) and Furtak (1986). According to their classification, cluster 1 presents the countries which belong to former parts of the Soviet Union, cluster 3 stands for the Soviet-controlled Eastern bloc countries and cluster 2 is a mixture of the previous two groups of countries. All the countries experienced a dramatic change within the communist bloc, which influence their political, economic and social life (Sion, 2018; Gandolfi et al., 2018). After the revolution, the countries started the process of transition to a market 
economy, presenting growing and developing markets nowadays. Important changes may have an impact on the operation of enterprises and their financial health and that is why the focus of the investigation is on these countries.

The research on the essence of financial ratios in the prediction of financial distress focuses on 180 models developed in transition countries. Together, there are 917 financial indicators identified in the models.

Tab. 1 - Most frequently used ratios in the prediction models. Source: own research

\begin{tabular}{|c|c|c|c|}
\hline Activity Ratios & Freq. & Liquidity Ratios & Freq. \\
\hline Total Sales/Total Assets & 38 & Current ratio & 61 \\
\hline Total Revenues/Total Assets & 12 & Working Capital/Total Assets & 30 \\
\hline Cash Flow/Total Assets & 10 & Quick ratio & 26 \\
\hline Cash Flow/Operating Revenues & 8 & Cash ratio & 22 \\
\hline Total Sales/Working Capital & 8 & Working Capital/Fixed Assets & 5 \\
\hline Total Sales/Current Assets & 7 & Short-term Assets/Total Assets & 7 \\
\hline Revenues from Sales/Total Assets & 7 & Equity/Long-term Assets & 7 \\
\hline Inventory/Total Sales & 6 & (Equity - Share Capital)/Total Assets & 5 \\
\hline $\begin{array}{l}\text { Inventory/Revenues from } \\
\text { Sales*365 }\end{array}$ & 5 & & 163 \\
\hline \multirow[t]{2}{*}{ Total Sales/ Total Liabilities } & 4 & & \\
\hline & 105 & & \\
\hline Profitability Ratios & Freq. & Debt Ratios & Freq. \\
\hline ROE & 33 & Total Liabilities/Total Assets & 39 \\
\hline $\mathrm{ROA}$ & 28 & Equity/Total Assets & 37 \\
\hline EBIT/Total Assets & 19 & Cash Flow/ Total Liabilities & 14 \\
\hline Operating Profit/Total Assets & 19 & Equity/ Total Liabilities & 12 \\
\hline ROS & 14 & Total Liabilities/Equity & 10 \\
\hline Retained Earnings/Total Assets & 11 & Total Assets/ Total Liabilities & 9 \\
\hline EBT/Total Assets & 8 & $\begin{array}{l}\text { (Current Assets + Accrued Assets)/ } \\
\text { (Current Liabilities + Accrued of Li- } \\
\text { abilities + Special Funds + Accrued } \\
\text { Revenue) }\end{array}$ & 6 \\
\hline EBT/Total Sales & 7 & Total Debts/Total Assets & 6 \\
\hline EBT from Sales/Operating Costs & 6 & Total Debts/Equity & 6 \\
\hline EBIT/Interest Expense & 6 & $\begin{array}{l}\text { Interest Income/(Profit from Eco- } \\
\text { nomic Activity + Interest Income) }\end{array}$ & 6 \\
\hline \multirow[t]{2}{*}{ EAT/Inventory } & 4 & Cash Flow/Total Debts & 5 \\
\hline & 155 & & 150 \\
\hline
\end{tabular}


Some of them are used almost in every study, especially the ones from the earliest studies, some of them are unique. We focus on those financial ratios which appear at least 4 times in all models (40 most frequently used ratios in transition economies). The intended financial ratios are depicted in Tabel 1 arranged in the basic groups of financial ratios: ratios of activity, liquidity, profitability and debt.

The results indicate that the most important one is the group of liquidity ratios which focus on a firm's ability to pay its short-term debt obligations. The most important one is the current ratio, which is a liquidity and efficiency ratio that measures a corporate ability to pay off its short-term liabilities using its current assets. The current ratio determines the liquidity as short-term liabilities are due in the period of the following year. A higher current ratio is always more favorable than a lower current ratio because it shows the company can more easily make current debt payments. The liabilities-to-total-assets ratio is the second most significant which measures the ratio of corporate assets covered by liabilities. A high liabilities-to-total-assets ratio can be negative, which indicates the shareholder equity is low and potential solvency issues. Enterprises in signs of financial distress will often have a high liabilities-to-total-assets ratio. The third one is the ratio of total sales to total assets, which quantifies the corporate efficiency focusing on the relation of assets to the revenue generated, therefore, the higher value of the ratio, the better it is for the company. Finally, the equity-to-asset ratio, which determines the financial health of an enterprise and is used to assess a company's financial leverage. If an enterprise wants to prove its sustainability and a low risk level, a higher level of the equity-to-asset ratio is needed to convince the creditors.

Despite the fact that some of the variables seem to have no differences, the reverse is true. For instance, the operating profit over the total assets ratio does not take financial profit into account. Discussing the differences between earnings before interest and taxes and return of assets, it should be highlighted that return of equity uses the net profit and thus allows assessing the corporate profitability without the effect of national taxation.

The dendogram of financial ratios captures the results of clustering of 40 most frequently used financial ratios; it is obvious that four main clusters are identified (Table 2).

Tab. 2 - Clusters of the analyzed financial ratios. Source: own research

\begin{tabular}{|l|l|}
\hline Cluster 1 & Cluster 4 \\
\hline Inventory/Revenues from Sales365 & Equity/Long-term Assets \\
\hline EAT/Inventory & Cash Flow/Total Debt \\
\hline Working Capital/Fixed Assets & Cash ratio \\
\hline (Equity - Share Capital)/Total Assets & Total Assets/ Total Liabilities \\
\hline $\begin{array}{l}\text { Interest Income/(Profit from Economic } \\
\text { Activity }+ \text { Interest Income) }\end{array}$ & Inventory/Total Sales \\
\hline EBT from Sales/Operating Costs & Total Revenues/Total Assets \\
\hline Revenues from Sales/Total Assets & ROE \\
\hline Cash Flow/Operating Revenues & Equity/Total Assets \\
\hline
\end{tabular}




\begin{tabular}{|l|l|}
\hline Total Sales/ Total Liabilities & ROA \\
\hline Total Sales/Working Capital & Total Sales/Total Assets \\
\hline EBT/Total Sales & Quick ratio \\
\hline $\begin{array}{l}\text { (Current Assets + Accrued Assets)/(Current } \\
\text { Liabilities + Accrued of Liabilities + Special } \\
\text { Funds + Accrued Revenue) }\end{array}$ & ROS \\
\cline { 2 - 2 } & Current ratio \\
\cline { 2 - 2 } & Cash Flow/ Total Liabilities \\
\hline Cluster 2 & Cash Flow/Total Assets \\
\hline Short-term Assets/Total Assets & Cluster 3 \\
\hline Equity/ Total Liabilities & \\
\hline EBIT/Interest Expense & \\
\hline Total Liabilities/Equity & EBT/Total Assets \\
\hline Total Debts/Total Assets & Working Capital/Total Assets \\
\hline Total Debts/Equity & EBIT/Total Assets \\
\hline Operating Profit/Total Assets & Retained Earnings/Total Assets \\
\hline Total Sales/Current Assets & Total Liabilities/Total Assets \\
\hline
\end{tabular}

The results of the cluster analyses focused on the groups of countries and financial ratios, create the input data of the correspondence analysis. To meet the preconditions of the correspondence analysis, the hypothesis of the independence of selected factors (financial ratios and countries) has to be tested using the Pearson Chi-square test of independence (Table 3).

As the p-value of the test is approximately zero, we reject the hypothesis about the independence of the factors (asymptotic significance is lower than the significance level of $1 \%$ ). The dependence between the groups of factors is measured by the Cramer's V coefficient, which confirms the statistically significant relation between the financial ratios and a country, where the prediction model was developed.

Tab. 3 - Test of independence of selected factors. Source: own research

\begin{tabular}{|l|l|l|l|}
\hline & Value & df & $\begin{array}{l}\text { Asymptotic Significance } \\
(2 \text {-sided })\end{array}$ \\
\hline Pearson Chi-Square & 30.301 & 6 & 0.000 \\
\hline Likelihood Ratio & 31.782 & 6 & 0.000 \\
\hline Linear-by-Linear Association & 0.332 & 1 & 0.564 \\
\hline N of Valid Cases & 573 & & \\
\hline
\end{tabular}

To reveal the mutual relationships among the categories, the authors are interested in the relation between row and column categories (Table $4 \mathrm{a}$ and $4 \mathrm{~b}$ ). 
Tab. $4 \mathrm{a}$ - Overview of row and column points (factors). Source: own research

\begin{tabular}{|c|c|c|c|c|c|c|c|c|c|}
\hline \multicolumn{10}{|c|}{ Overview row pointsa } \\
\hline \multirow{3}{*}{ 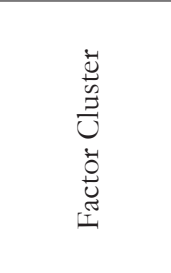 } & \multirow{3}{*}{ 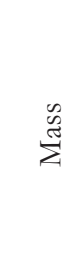 } & \multicolumn{2}{|c|}{$\begin{array}{l}\text { Score in Di- } \\
\text { mension }\end{array}$} & \multirow{3}{*}{ 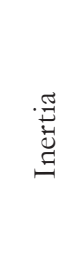 } & \multicolumn{5}{|c|}{ Contribution } \\
\hline & & 1 & 2 & & \multicolumn{2}{|c|}{$\begin{array}{l}\text { Of Point to } \\
\text { Inertia of Di- } \\
\text { mension }\end{array}$} & \multicolumn{3}{|c|}{$\begin{array}{l}\text { Of Dimension to Iner- } \\
\text { tia of Point }\end{array}$} \\
\hline & & & & & 1 & 2 & 1 & 2 & TOTAL \\
\hline Factor1 & 0.250 & -0.191 & 0.189 & 0.001 & 0.069 & 0.473 & 0.878 & 0.122 & 1.000 \\
\hline Factor2 & 0.250 & 0.016 & 0.056 & 0.000 & 0.000 & 0.041 & 0.368 & 0.632 & 1.000 \\
\hline Factor3 & 0.250 & 0.578 & -0.065 & 0.011 & 0.627 & 0.055 & 0.998 & 0.002 & 1.000 \\
\hline Factor4 & 0.250 & -0.403 & -0.181 & 0.006 & 0.304 & 0.430 & 0.972 & 0.028 & 1.000 \\
\hline Active Total & 1.000 & & & 0.018 & 1.000 & 1.000 & & & \\
\hline
\end{tabular}

Tab. 4b - Overview of row and column points (countries). Source: own research

\begin{tabular}{|c|c|c|c|c|c|c|c|c|c|}
\hline \multicolumn{10}{|c|}{ Overview column pointsa } \\
\hline \multirow{3}{*}{ 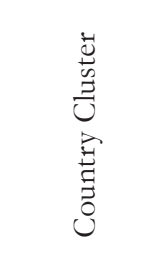 } & \multirow{3}{*}{ 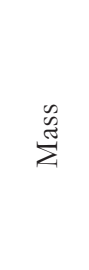 } & \multicolumn{2}{|c|}{$\begin{array}{l}\text { Score in Dimen- } \\
\text { sion }\end{array}$} & \multirow{3}{*}{ 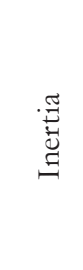 } & \multicolumn{5}{|c|}{ Contribution } \\
\hline & & \multirow[t]{2}{*}{1} & \multirow[t]{2}{*}{2} & & \multicolumn{2}{|c|}{$\begin{array}{l}\text { Of Point to } \\
\text { Inertia of } \\
\text { Dimension }\end{array}$} & \multicolumn{3}{|c|}{$\begin{array}{l}\text { Of Dimension to Inertia } \\
\text { of Point }\end{array}$} \\
\hline & & & & & 1 & 2 & 1 & 2 & TOTAL \\
\hline Country1 & 0.333 & 0.388 & -0.129 & 0.007 & 0.376 & 0.291 & 0.985 & 0.015 & 1.000 \\
\hline Country2 & 0.333 & -0.489 & -0.062 & 0.011 & 0.598 & 0.068 & 0.998 & 0.002 & 1.000 \\
\hline Country3 & 0.333 & 0.102 & 0.191 & 0.001 & 0.026 & 0.641 & 0.665 & 0.335 & 1.000 \\
\hline Active Total & 1.000 & & & 0.018 & 1.000 & 1.000 & & & \\
\hline
\end{tabular}

The most important results can be found in the column TOTAL, which depicts the proportion of column (row) points on the total inertia. The results prove that in both cases, the two-dimensional correspondence map represents the individual categories appropriately, as the contributions are equal to one in all cases.

The results show that it makes sense to explore the internal structure of the contingency table (Table 5) in the correspondence analysis.

Tab. 5 - Contingency table of the correspondence analysis. Source: own research

\begin{tabular}{|l|l|l|l|l|}
\hline Factor Cluster & \multicolumn{4}{l|}{ Country Cluster } \\
\hline & Country1 & Country2 & Country3 & TOTAL \\
\hline Factor1 & 0 & 22 & 49 & 71 \\
\hline
\end{tabular}




\begin{tabular}{|l|l|l|l|l|}
\hline Factor2 & 4 & 15 & 42 & 61 \\
\hline Factor3 & 19 & 17 & 83 & 119 \\
\hline Factor4 & 15 & 92 & 215 & 322 \\
\hline TOTAL & 38 & 146 & 389 & 573 \\
\hline
\end{tabular}

The results of the correspondence analysis provide factor scores for both row and column points of the contingency table. As the problem is symmetrically defined, row and column profiles are identical. It is not important how far a row point is from the column point. However, the directions of columns and rows from the origin play a crucial role. These coordinates graphically portray the relation and combination between the row and column elements in the contingency table; the result is an individual correspondent map both for row and column profiles. The overlay of both corresponding maps, i.e. a map of row profiles with a map of column profiles, portrays the symmetric correspondence map (Figure 1).

The results of the realized cluster and correspondence analyses reveal that the prediction models developed in former countries of the Soviet Union (Belarus, Estonia, Croatia and Latvia in the cluster 1) use the financial ratios grouped in cluster 3, which consists of three profitability ratios, two debt ratios and a liquidity ratio. The non-Soviet Union, but Soviet-controlled Eastern bloc of countries (Czech Republic, Slovakia, Romania and Poland in the cluster 3) prefer financial ratios in clusters 1 and 2 in developing the prediction models. The mix of transition countries grouped in cluster 2 (Lithuania, Russia, Hungary and Ukraine) focuses on financial ratios in cluster 4 , which is formed of nations with the same number of activity, liquidity, profitability and debt ratios. The research results confirm that a dependence exists between a financial ratio and a country in which a ratio is preferred in the prediction of corporate financial distress.

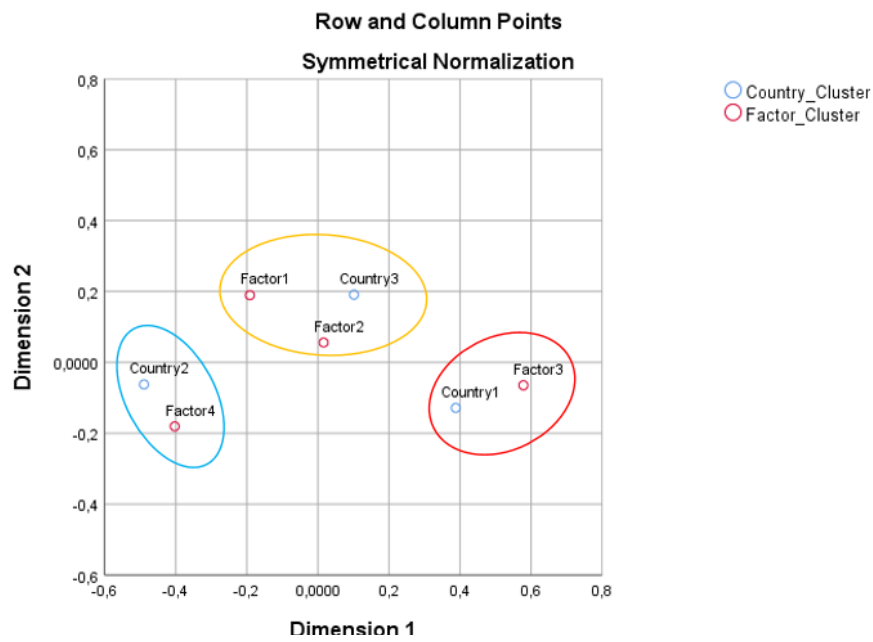

Fig. 1 - Symmetric correspondence map. Source: own research 
Sundry financial ratios have been described in the literature which are used either to predict bankruptcy or to reveal the financial problems of enterprises. The interest of various authors in the significant and frequently used indicators to assess the financial distress is high, however, we will mainly consider two important studies with which to compare the results of our findings Bellovary et al. (2007) and Ravi \& Ravi (2007).

Bellovary et al. (2007) analyzed 165 predictive models developed before 2004 in which 752 different variables were used in the models, with up to 674 of these variables used in only one or two models. In the conclusion of the study, 42 variables are presented which were used in more than five models. However, the most frequently used are the EAT-to-total assets ratio, currentassets-to-short-term-liabilities ratio, working-capital-to-total-assets ratio and retained-earningsto-total-assets ratio, all of which appeared in more than 40 of the models considered. Ravi \& Ravi (2007) followed the previously published studies by Calderon et al. (2002), Dimitras et al. (1996), O'Leary (1998) and Scott (1981). All together Ravi \& Ravi (2007) analyzed 62 prediction models and ranked the significance of the financial predictors, marking the EAT-to-total-assets the most important financial indicators followed by the retained-earnings-to-total-assets ratio and the sales-to-total-assets ratio. Based on the reviews of previously published studies, Kliestik et al. (2019) selected the financial indicators for the formation of the Slovak prediction model which appear to be the most relevant and frequently used in Visegrad countries. Comparing the results of all the mentioned studies of financial predictors, no financial characteristics were common to all the predictive studies. The ratios found useful in earlier studies (Altman, 1968) were the first under consideration by many researchers, and these ratios were subsequently used in later studies. Analyzing the prediction models developed in Eastern European countries, 40 of the most popular and frequently used financial indicators were identified. The question is if these indicators are consistent with the crucial financial ratios determined in the presented studies (Janoskova \& Kral, 2019). A mutual comparison of all the ratios indicates that 22 of the 41 financial indicators proposed by Bellovary at el. (2007), 15 out of 20 in the research of Ravi \& Ravi (2007), and 20 out of 37 financial ratios determined in the research of Kliestik et al. (2019) correspond with the ratios identified in the study of the most preferred financial ratios in the prediction models developed in the transition economies described in the paper.

The analysis of financial ratios is an important part of the assessment of the future financial development of a company. Moreover, this analysis can reveal financial distress and thus enable the company to be prepared for potential changes in its financial structure. Biernacka \& Sedliacikova (2006), and Cepel et al. (2018) confirm that financial data are the best indication of a company's problems, especially considering that falling profits and losses can be seen as a deteriorating level of competitiveness compared to other industry representatives.

\section{CONCLUSION}

Different financial problems of business entities may be revealed using bankruptcy prediction modelling. Moreover, having information about future financial stability, an enterprise can adopt appropriate financial decisions and thus preserve or even adjust its market competitiveness. The relevance of the research in this field is underscored by the fact that knowing information about 
corporate financial health in the ensuing period eliminates potential financial risks. General corporate prosperity and financial stability is assessed by the crucial financial ratios identified as well as other characteristics of enterprises along with the economic and national environments in which they operate.

To clarify the role of the financial ratios in the prediction of financial distress in an analysis encompassing samples of business entities from multiple countries with transition economies, the authors applied several statistical methods to reveal the dependence among financial ratio and country of model origin. In our study, which was based on a cluster analysis, categorical data and a correspondence analysis, we confirmed that particular groups of countries prefer different financial ratios in developing a model of prediction of financial distress. The results of the cluster and correspondence analyses performed reveal that the prediction models developed in Belarus, Estonia, Croatia and Latvia use a total-liabilities-to-total-assets ratio, working-capitalto-total-assets ratio, and EBIT-to-total-assets ratio most frequently. The countries of the former Soviet-controlled Eastern bloc (Czech Republic, Slovakia, Romania and Poland) prefer mostly an operating-profit-to-total-assets ratio, total-assets-to-total-liabilities ratio, and total-sales-toworking-capital ratio (taking into account the frequency of their usage). Lithuania, Russia, Hungary and Ukraine focus most commonly on the use of a current ratio, total-sales-to-total-assets ratio, equity-to-total assets ratio, and return of equity.

Despite our extensive review, calculations and analyses, some limitations can be identified in the research. We attempted to detect the role of financial ratios in the prediction of financial distress in selected transition economies using the vast majority of Eastern European countries. Thus, it would be beneficial to also unveil the importance and significance of financial ratios in other European or even American countries and to compare the results with ours. It would be also useful to determine the impact of the statistical method on the use of financial ratios in the prediction models. We would undertake this in future research, as well as the application of other statistical methods - principal component analysis and factor analysis - to validate the results of the presented research. The results of this research may be used by other enterprises or investors in evaluating and analysing the financial health of an enterprise in the specific conditions of the selected Eastern European countries. Moreover, an indication of positive development in the future is a sign that a strong competitive position is being built, an outcome which may be used as an effective assessment criteria for market analysts. Finally, making clear, educated choices regarding which specific indicators to use within a specific country may be very helpful for academicians in developing models in particular economic conditions.

\section{Acknowledgements}

This research was financially supported by the Slovak Research and Development Agency-Grant No. APVV14-0841: Comprehensive Prediction Model of the Financial Health of Slovak Companies and is an output of the scientific project VEGA 1/0428/17 Creation of new paradigms of financial management at the threshold of the 21 st century in the conditions of the Slovak Republic.

\section{References}

1. Altman, E. (1968). Financial ratios, discriminant analysis and the prediction of corporate bankruptcy. Journal of Finance, 23 (4). https://doi.org/10.1111/j.1540-6261.1968.tb00843.x 
2. Andrés, J., Landajo, M., \& Lorca, P. (2012). Bankruptcy prediction models based on multinorm analysis? An alternative to accounting ratios. Knowledge-Based Systems, 30, 67-77. http://dx.doi.org/10.1016/j.knosys.2011.11.005

3. Antonowicz, P. (2014). The analysis of ranges of variability of selected ratios from a group of assets productivity ratios three years before the declaration of bankruptcy by companies in Poland. Business and Economic Horizons, 10 (3), 202-213. http://dx.doi.org/10.15208/ beh.2014.17

4. Asquith, P., Gertner, R., \& Scharfstein, D. (1994). Anatomy of financial distress: An explanation of junk bond issuers. The Quarterly Journal of Economics, 109 (3), 625-658. https:// doi.org/10.2307/2118416

5. Bahiraie, A., Azhar, A.K.M., \& Ibrahim, N.A. (2011). A new dynamic geometric approach for empirical analysis of financial ratios and bankruptcy. Journal of Industrial and Management Optimization, 7 (4), 947-965. http://dx.doi.org/10.3934/jimo.2011.7.947

6. Beaver, W.H., McNichols, M.F., \& Rhie, J.W. (2005). Have financial statements become less informative? Evidence from the ability of financial ratios to predict bankruptcy. Review of Accounting Studies, 10 (1), 93-122. https://doi.org/10.1007/s11142-004-6341-9

7. Beaver, W.H., Correira, M., \& McNichols, M.F. (2012). Do differences in financial reporting attributes impair the predictive ability of financial ratios for bankruptcy? Review of Accounting Studies, 17, 969-1010. https://doi.org/10.1007/s11142-012-9186-7

8. Beaver, W. (1966). Financial ratios as predictors of failure. Journal of Accounting Research, 4 (3), 71-111.

9. Belas, J., Cipovova, E., Novak, P. \& Polach, J. (2012). Impacts of the Foundation Internal Ratings Based Approach Usage on Financial Performance of Commercial Bank. $E+M$ Ekonomie a Management, 15 (3), 142-154.

10. Belas, J., Gavurova, B., \& Toth, P. (2018a). Impact of selected characteristics of SMES on the capital structure. Journal of Business Economics and Management, 19 (4), 592-608.

11. Belas, J., Smrcka, L., Gavurova, B., \& Dvorsky, J. (2018b). The Impact of Social and Economic Factors in the Credit Risk Management of SME. Technological and Economic Development of Economy, 24 (3), 1215-1230.

12. Bellovary, J., Giacomino, D., \& Akers, M. (2007). A review of bankruptcy prediction studies: 1930 to present. Journal of Financial Education, 33, 1- 43.

13. Biernacka, J., \& Sedliacikova, M. (2006). Selected ratio and bankruptcy early-warning method analysis of competitiveness of wood sector companies listed on Warsaw Stock Exchange. Drvna Industrija, 63 (3), 187-193. https://doi.org/10.5552/drind.2012.1212

14. Bukharin, N.I., \& Preobrazhensky, E.A. (2007). The ABC of Communism. UK: Merlin Press.

15. Calderon, T.G., \& Cheh, J.J. (2002). A roadmap for future neural networks research in auditing and risk assessment. International Journal of Accounting Information Systems, 3 (4), 203-236. https://doi.org/10.1016/S1467-0895(02)00068-4

16. Cepel, M., Stasiukynas, A., Kotaskova, A., \& Dvorsky, J. (2018). Business Environment Quality Index in the SME Segment. Journal of Competitiveness, 10 (1), 21-40. https://doi. org/10.7441/joc.2018.02.02 
17. Clausen, S.E. (1998). Quantitative applications in the social sciences. Applied correspondence analysis: An introduction. Canada: Sage Publications.

18. Darmawan, A., \& Supriyanto, J. (2018). The effect of financial ratio on financial distress in predicting bankruptcy. Journal of Applied Managerial Accounting, 2 (1), 110-120. https://doi. org/10.30871/jama.v2i1.727

19. Dimitras, A.I., Zanakis, S.H., \& Zopoundis, C. (1996). A survey of business failure with an emphasis on prediction method and industrial applications. European Journal of Operational Research, 90 (3), 487-513.

20. Dobrovic, J., Lambovska, M., Gallo, P., \& Timkova, V. (2018). Non-financial indicators and their performance in small and medium-sized enterprises. Journal of Competitiveness, 10 (2), 41-55. https://doi.org/10.7441/joc.2018.02.03

21. Fitzpatrick, F. (1932). A comparison of ratios of successful industrial enterprises with those of failed firm. Certified Public Accountant, 6, 727-731.

22. Fogarassy, C., Neubauer, E., Mansur, H., Tangl, A., Olah, J., \& Popp, J. (2018). The main transition management issues and the effects of environmental accounting on financial performance - with focus on cement industry. Administratiesi Management Public, 31, 52-66. https://doi.org/1024818 /amp/2018.31-04

23. Furtak, R.K. (1986). The political systems of the Socialist States: An Introduction to Marxist-Leninist Regimes. Brighton, UK: Wheatsheaf.

24. Gandolfi, G., Regalli, M., Soana, M.G., \& Arcuri, M.C. (2018). Underpricing and long-term performance of IPOs: Evidence from European intermediary-oriented markets. Economics, Management and Financial Markets, 13 (3), 11-36. https://doi.org/10.22381/EMFM13320181

25. Garcia, V., Marques, A.I., \& Salvador Sanchez, J. (2019). Exploring the synergetic effects of sample types of the performance of ensembles for credit risk and corporate bankruptcy prediction. Information Fusion, 47, 88-101. https://doi.org/10.1016/j.inffus.2018.07.004

26. Gavurova, B., Belas, J., Kocisova, K., \& Kliestik, T. (2017). Comparison of selected methods for performance evaluation of Czech and Slovak commercial banks. Journal of Business Economics and Management, 18 (5), 852-876.

27. Goldson, M. (1992). The turnaround prescription. New York, NY: Macmilan.

28. Hexmoor, H. (2016). Computational network science: An algorithmic approach. 1st edition. USA: Morgan Kaufmann Publishers.

29. Hosaka, T. (2019). Bankruptcy prediction using imaged financial ratios and convolutional neural networks. Expert Systems with Applications, 117, 287-299. https://doi.org/10.1016/j. eswa.2018.09.039

30. Hudakova, M., Masar, M., Luskova, M., \& Patak M.R. (2018). The Dependence of Perceived Business Risks on the Size of SMEs. Journal of Competitiveness, 10 (4), 54-69. https://doi. org/10.7441/joc.2018.04.04

31. Ishtiaq, A., Olah, J., Popp, J., \& Mate, D. (2018). Does business group affiliation matter for superior performance? Evidence from Pakistan. Sustainability, 10 (9), 3060. https://doi. org/10.3390/su10093060 
32. Janoskova, K., \& Kral, P. (2019). An In-Depth Analysis of the Summary Innovation Index in the V4 Countries. Journal of Competitiveness, 11 (2), 68-83. https://doi.org/10.7441/ joc.2019.02.05

33. Kliestik, T., Misankova, M., Valaskova, K., \& Svabova, L. (2018). Bankruptcy prevention: New efforts to reflect on legal and social changes. Science and Engineering Ethics, 24 (2), 791-803.

34. Kliestik, T., Valaskova, K., Kliestikova, J., Kovacova, M., \& Svabova, L. (2019). Bankruptcy prediction in transition economies. Zilina, SR: EDIS.

35. Kljucnikov, A., Kozubikova, L., \& Sopkova, G. (2017). The Payment Discipline of Small and Medium-sized Enterprises. Journal of Competitiveness, 9 (2), 45-61. https://doi. org/10.7441/joc.2017.02.04

36. Kral,P., Kanderova, M., Kascakova, A., Nedelova, G., \& Valencakova, V. (2009). Multivariate statistical methods with a focus on problem solving in economic practice. Banska Bystrica, SR: Matej Bel University.

37. Le, T., Lee, M.Y., Park, J.R., \& Baik, S.W. (2018). Oversampling techniques for bankruptcy prediction: Novel features from a transaction dataset. Symmetry-Basel, 10 (4), 79. https://doi. $\operatorname{org} / 10.3390 /$ sym10040079

38. Lukason, O., \& Laitinen, K.K. (2019). Firm failure processes and components of failure risk: An analysis of European bankrupt firms. Journal of Business Research, 88, 380-390. https://doi.org/10.1016/j.jbusres.2018.06.025

39. O’Leary, D.E. (1998). Using neural network to predict corporate failure. International Journal of Intelligent Systems in Accounting, Finance and Management, 7, 187-197.

40. Ouenniche, J., Perez-Gladish, B., \& Bouslah, K. (2018). An out-sample framework for TOPSIS-based classifiers with application in bankruptcy prediction. Technological Forecasting and Social Change, 131, 111-116. https://doi.org/10.1016/j.techfore.2017.05.034

41. Platt, H., \& Platt, M. (2002). Predicting corporate financial distress: Reflections on choicebased sample bias. Journal of Economics and Finance, 26 (2), 184-199. https://doi.org/10.1007/ BF02755985.

42. Rahman, A., Belas, J., Kliestik, T., \& Tyll, L. (2017). Collateral requirements for SME loans: empirical evidence from the Visegrad countries. Journal of Business Economics and Management, 18 (4), 650-675, doi: 10.3846/16111699.2017.1357050

43. Ravi, K. P., \& Ravi, V. (2007). Bankruptcy prediction in banks and firms via statistical and intelligent techniques - A review. European Journal of Operational Research, 180 (1), 1-28.

44. Scott, J. (1981). The probability of bankruptcy: A comparison of empirical predictions and theoretical models. Journal of Banking \& Finance, 5 (3), 317-344.

45. Sharifabadi, M.R., Mirhaj, M., \& Izadinia, N. (2017). The impact of financial ratios on the prediction of bankruptcy of small and medium companies. Quid, 1, 164-173.

46. Sion, G. (2018). How artificial intelligence is transforming the economy. Will cognitively enhanced machines decrease and eliminate tasks from human workers through automation? Journal of Self-Governance and Management Economics, 6 (4), 31-36. https://doi.org/10.22381/ JSME6420185 
47. Stevens, J.P. (2002). Applied multivariate statistics for the social sciences. New Jersey, US: Lawrence Erlbaum.

48. Svabova, L., Kramarova, K., \& Durica, M. (2018). Prediction model of firm's financial distress. Ekonomicko-manazerske spectrum, 12 (1), 16-29. dx.doi.org/10.26552/ems.2018.1.1629

49. Tian, S., Yu, Y., \& Guo, H. (2015). Variable selection and corporate bankruptcy forecasts. Journal of Banking \& Finance, 52, 89-100. https://doi.org/10.1016/j.jbankfin.2014.12.003

50. Turetsky, H., \& McEwen, R. (2001). An empirical investigation of firm longevity: A model of the ex-ante predictors of financial distress. Review of Quantitative Finance and Accounting, 16, 323-343. https://doi.org/10.1023/A:1011291425075

51. Valaskova, K., Kliestik, T., \& Kovacova, M. (2018). Management of financial risks in Slovak enterprises using regression analysis. Oeconomia Copernicana, 9 (1), 105-121. https://doi. org/10.24136/oc.2018.006

52. Virag, M. (2004). Financial analysis, bankruptcy prediction. Budapest: Szinkron Press.

53. Vochozka, M. (2017). Formation of complex company evaluation method through neural networks based on the example of construction companies' collection. Ad Alta-Journal of Interdisciplinary Research, 7 (2), 232-239.

54. Zelenkov, Y., Fedorova, E., \& Chekrizov, D. (2017). Two-step classification method based on genetic algorithm for bankruptcy forecasting. Expert Systems with Applications, 88, 393-401. https://doi.org/10.1016/j.eswa.2017.07.025

\section{Contact information}

prof. Ing. Tomas Kliestik, PhD.

University of Žilina

Faculty of Operation and Economics of Transport and Communications

Department of Economics

Slovakia

E-mail:tomas.kliestik@fpedas.uniza.sk

ORCID: 0000-0002-3815-5409

Ing. Katarina Valaskova, Ph.D.

University of Žilina

Faculty of Operation and Economics of Transport and Communications

Department of Economics

Slovakia

E-mail:katarina.valaskova@fpedas.uniza.sk.

ORCID: 0000-0003-4223-7519

assoc. prof. George Lazaroin

Spiru Haret University

Faculty of Social and Human Sciences, Department of Social Human Sciences

Romania

E-mail:phd_lazaroin@yahoo.com 
Ing. Maria Kovacova, Ph.D.

University of Žilina

Faculty of Operation and Economics of Transport and Communications

Department of Economics

Slovakia

E-mail:maria.kovacova@fpedas.uniza.sk.

ORCID: 0000-0003-2081-6835

Ing. Jaromir Vrbkea, $M B A, P h D$.

Institute of Technology and Business in Ceské Budèjovice

Crech Republic

E-mail:vrbka@mail.vstecb.cr. 